\title{
Comparative Study on the Hydraulic Characteristics of Nature-Like Fishways
}

\author{
Tiegang Zheng ${ }^{1}$, Zhipan Niu ${ }^{2} * \mathbb{D}^{\mathbb{D}}$, Shuangke Sun ${ }^{1}$, Jiayue Shi ${ }^{3}$, Haitao Liu ${ }^{1}$ and Guangning $\mathrm{Li}^{1}$ \\ 1 State Key Laboratory of Simulation and Regulation of Water Cycle in River Basin, China Institute of Water \\ Resources and Hydropower Research, Beijing 100038, China; zhengtg@iwhr.com (T.Z.); \\ sunsk@iwhr.com (S.S.); htliou@163.com (H.L.); lgnchina@163.com (G.L.) \\ 2 Institute for Disaster Management and Reconstruction, Sichuan University, Chengdu 610207, China \\ 3 Power china Huadong Engineering Corporation, Hangzhou 311122, China; shi_jy@ecidi.com \\ * Correspondence: niuzhipan@sina.com; Tel.: +86-28-8599-6656
}

Received: 24 February 2020; Accepted: 25 March 2020; Published: 27 March 2020

\begin{abstract}
Due to the complex structure and the multiformity of boulder arrangements, there is currently no perfect design criterion for nature-like fishways. This paper proposes four types of nature-like fishways arranged with an impermeable partition wall (IPW), a semi-permeable partition wall (SPPW) or a fully permeable partition wall (FPPW). The hydraulic characteristics of these fishways were investigated experimentally. The results show that the discharge of the fishway arranged with a FPPW was almost twice that of an IPW fishway, and the discharge of a SPPW fishway was between the two extremes. The mean flow velocity of the FPPW fishway was larger than that of the other schemes. For the fishway arranged with an IPW, the flow information was basically consistent with that of the engineered technical fishway. In the FPPW or SPPW fishway, there was more abundant flow information and no obvious recirculation zones in the fishway pool, and these conditions are suitable for migratory fish moving up- and downstream. Notably, for the fishway arranged with two fish passages, two mainstreams were formed in the pool, which divided the flow pattern of the pool into three flow regions. A weak recirculation area was formed in the low-velocity region, which facilitates swimming for migratory fish. According to this comprehensive comparative study, the SPPW fishway with two fish passages had low discharge, abundant flow information and favorable fish migration characteristics; thus, it is the optimal fishway scheme among those studied in this paper.
\end{abstract}

Keywords: nature-like fishway; hydraulic characteristics; impermeable partition wall; semi-permeable partition wall; fully permeable partition wall

\section{Introduction}

Fishways are special facilities that enable fish to migrate through obstacles such as dams, and they play an irreplaceable role in maintaining the continuity of rivers and the intercommunion between different fish species [1,2]. The success or failure of a fishway is the evaluating indicator of the health of a river ecosystem, which is also an important ecological indicator for hydropower engineering $[3,4]$. Nature-like fishways are very popular all over the world at present $[5,6]$. Compared with traditional engineering fishways, nature-like fishways are advantageous for fish passage because of the familiar flow patterns for fish [7]. A nature-like fishway is suitable for the upstream migration of many kinds of fish, especially for gated dam projects with large dam widths and low water heads [8].

Since their initial construction, nature-like fishways have been widely used in Germany, Switzerland, Finland, Australia, Japan and many other countries [9-11]. Nature-like fishways are built with diverse materials, such as combinations of gravel, rocks, boulders, wood and riparian 
vegetation, to imitate natural stream geomorphological conditions. Thus, they create more diverse flow conditions within a cross-section than standard fishways and are amenable to many species of fish $[7,12,13]$. After some nature-like fishways were built, monitoring and evaluation were carried out. Aarestrup et al. [14] used the passive integrated transponder (PIT) technique to monitor the fish passing situation in a nature-like bypass fishway in Denmark. The monitoring results showed that over $90 \%$ of target fish could enter the fishway, but the passing rate was only about $55 \%$, which was affected by the overlength and the excessive flow velocity in the fishway. Kim et al. [15] also used PIT to investigate the effectiveness of the nature-like fishway installed at Sangju Weir on the Nakdong River, Korea. The monitoring results showed that $63.2 \%$ of the fish tested could pass through the fishway, and some of the fish were found to stay inside the fishway for more than 28 days, which means that the nature-like fishway has uses other than fish passing. Comparing the passage efficiency of the nature-like fishway, denil fishway, vertical slot fishway and weir-type fishway, Bunt et al. [7] pointed out that the upstream migration rate of fish in the nature-like fishway was the highest. It can be seen from the monitoring results that the flow structure in a nature-like fishway is obviously diversified, and the flow condition is suitable for different kinds of aquatic organisms.

The hydrodynamics of conventional fishways have been studied for many years, but the same is not true for nature-like fishways [8,16]. Although the design principles in geometry and many examples of implementation of such nature-like fishways have been presented $[17,18]$, it is difficult to establish uniform dimensions for nature-like fishways, such as the distance of boulders, the shapes of boulders and their arrangement, which are important indexes that influence the hydraulic characteristics of nature-like fishways [19-23]. Therefore, in the past few years, studies of nature-like fishways have always focused on the shape or the arrangement of boulders. For example, Acharya et al. [24] performed a comparative study of the hydraulic characteristics of two different kinds of nature-like fishways, focusing on the analysis of how the hemispherical tectonic structure, cylindrical tectonic structure and square tectonic structure of the fish channel influenced the downstream migration of fish. Similarly, Muraoka et al. [19] studied how the shape, arrangement and height of the boulders influenced the migration of fish in the rock-ramp-type fishway, a nature-like fish pass with a staggered arrangement of boulders, via physical experiments. Baki et al. [25] put forward a design scheme for a rock-ramp-type fishway and studied the mean flow characteristics at three different slopes (5\%, 3\% and $1.5 \%$ ). It was found that this type of fish pass can produce an adequate water depth and favorable flow velocity suitable for fish passage. Baki et al. [26] also examined the turbulence characteristics of a rock-ramp-type fishway considering slopes of $1.5 \%$ and $3 \%$ tested under different discharges. It should be pointed out that there are some major differences between the flow with a cluster of boulders (wake-interference flow) and the flow with isolated boulders (isolated-roughness flow) in the decay rate of turbulence and the turbulence magnitude. In addition, some researchers, such as Tran et al. [20] and He et al. [27], have used numerical simulations to study the layout of boulders in nature-like fishways and put forward some layout proposals. Wang and Hartlieb [16] presented a verification of the hydraulic and geometric parameters of nature-like pool-type fish passes via experimental and field investigations. Additionally, some researchers have also put forward many types of fishways piled with boulders [28,29]. However, most materials of partition walls formed by boulders in the above-mentioned nature-like fishways are impermeable; such fishways are actually imitations of engineered technical fishways, and not really nature-like fishways. Because of the diversity of the placement and arrangement of boulders in nature-like fishways, the layout of nature-like fishways has remained in the stage of optimization and exploration in recent years [16].

Plenty of research has shown that when a river is blocked by gated dams, a nature-like fishway is the best alternative scheme to guarantee an unblocked ecosystem. However, because of the complexity of the structure, the variability of section types, the high roughness of the slope and bottom material and the difficulty in estimating the roughness coefficient of nature-like fishways, neither the perfect research method nor design criterion for nature-like fishways has been formed to date, especially for the layout of a fishway piled with boulders [16,30]. This paper presents a new fishway type formed by 
a rubble wall. The hydraulic characteristics of fishways formed under impermeable, semi-permeable and fully permeable rubble wall conditions are comparatively analyzed, which could provide the basis for the engineering design and application of nature-like fishways.

\section{Materials and Methods}

\subsection{Experimental Arrangements and Instruments in the Model Test}

Figure 1 shows a schematic diagram of the model design. The model included an impounding pool, a test section in the fishway and a tail pool. The tail pool and the impounding pool were connected by a groundwater reservoir. Four fishway types, with impermeable, semi-permeable and fully permeable rubble walls, were arranged in the test section. The cross-section of the fishway was trapezoidal, as shown in Figure 1. The length of the fishway test section $(L)$ was $17 \mathrm{~m}$, including a total of 11 fishway pools, and the longitudinal slope $(J)$ was $1 \%$. The bottom and the side slope of the fishway were smoothed by concrete. The bottom width (a) was $0.75 \mathrm{~m}$, and the side slope $\left(i_{a}\right)$ was 1:2.5. The flow velocity and flow patterns were analyzed, as described in the following paragraphs, by taking the fish channel and the intermediate pond in the fishway test section as typical research objects. Figure 2 shows a picture of the original experimental model.

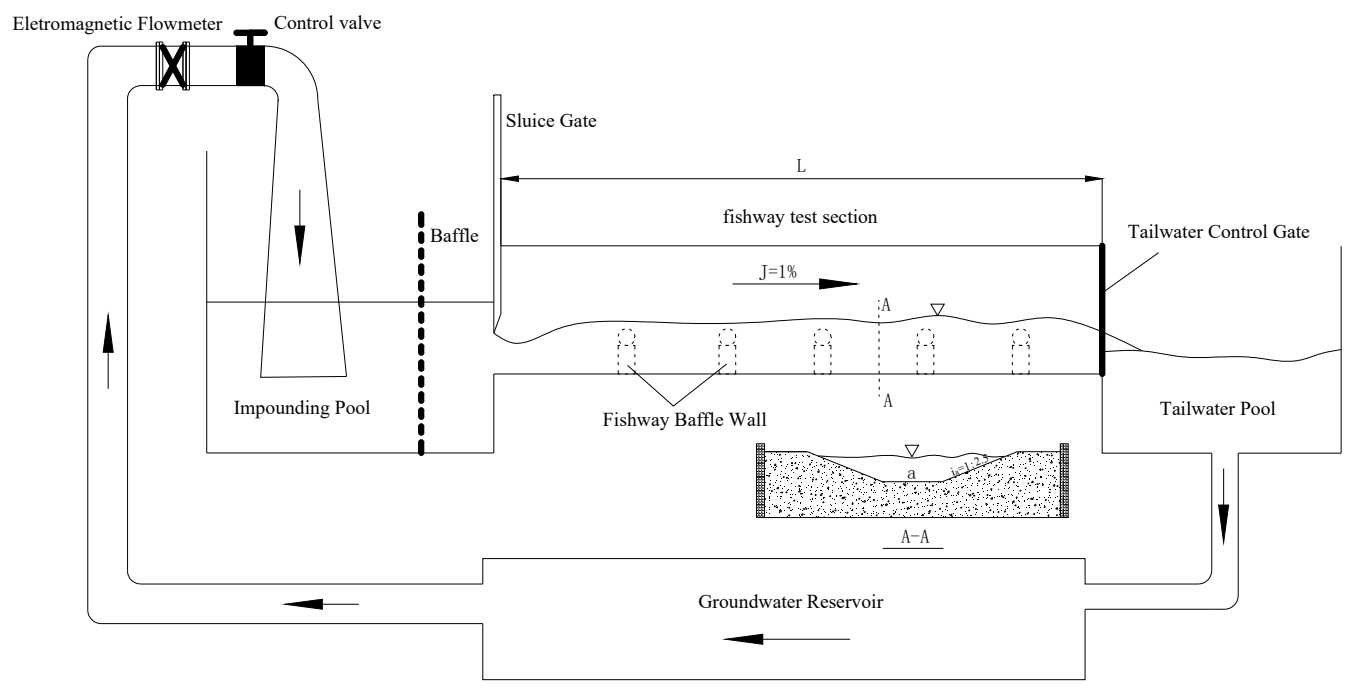

Figure 1. Scheme of the experimental flume, representing a side view of the channel on a slope of $1 \%$ with the location of impounding area, test area and tailwater area. " $\mathrm{A}$ " represents the cross section number and "A-A" refers to the cross section of the experimental flume with a 1:2.5 side slope $\left(i_{a}\right)$. $L=$ length of the fishway test section; $J$ = longitudinal slope; $\mathrm{a}=$ bottom width.

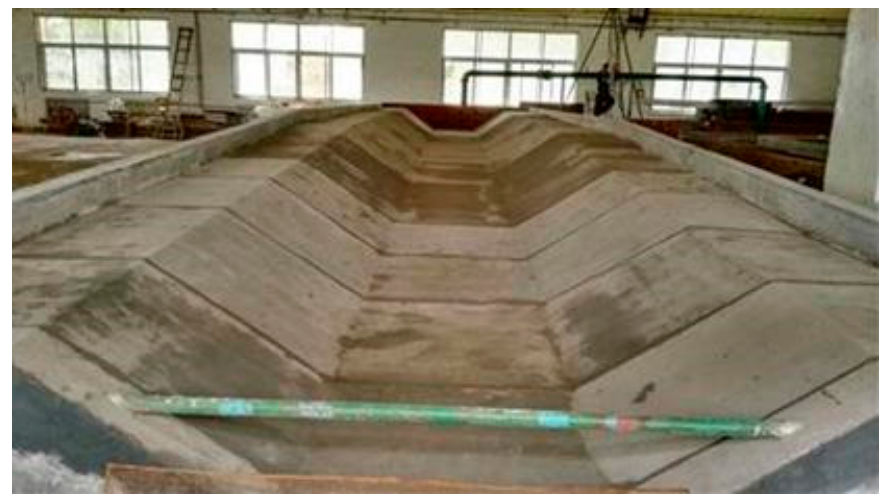

Figure 2. Picture of the original experiment flume without roughening, facing upstream. The materials of the bottom and side slope are concrete. 
According to the uniform flow theory in an open channel, the roughness coefficient $(n)$ of the open channel can be expressed as:

$$
n=\frac{A}{Q} R^{2 / 3} i^{1 / 2},
$$

In the above formula, $A$ is the wetted cross-sectional area of the open channel, $Q$ is the flow discharge, $R$ is the hydraulic radius and $i$ is the channel slope.

According to the cross-sectional dimension of the model, the wetted cross-sectional area of the open channel can be expressed as:

$$
A=h(b+m h)=h(0.75+2.5 h),
$$

The corresponding wetted perimeter can be expressed as:

$$
\chi=b+2 h \sqrt{1+m^{2}}=0.75+5.3852 h,
$$

The corresponding hydraulic radius can be expressed as:

$$
R=\frac{A}{\chi}=\frac{h(0.75+2.5 h)}{0.75+5.3852 h} .
$$

In the above formula, $h$ is the depth of the water, $b$ is the width of the bottom, $m$ is the slope ratio of the channel and $\chi$ is the wetted perimeter. The literature indicates that when the angle between the slope and the horizontal is less than $6^{\circ}$, the hydraulic gradient $J$ can be used as an approximation to replace the channel gradient $I$; therefore, the channel roughness value can be solved by knowing the upstream flow rate and the uniform flow depth.

By adjusting the water depth and flow rate in the channel, the channel roughness was calculated using three scenarios (Table 1). Scenario I was the original scheme with no roughening, and the average roughness of the channel was measured to be 0.012 , as shown in Table 1 . In actual engineering, in order to reduce the flow velocity in the fishway pool, sand gravels are usually laid at the bottom and slope of the pools, which can increase the roughness of the fishway and bring the flow information in the fishway much closer to a natural river channel.

Table 1. Roughness calculation table of the test under three schemes with nine scenarios. "Original roughness" represents a scheme without roughening. "Bottom roughness" refers to a scheme with roughening at the bottom only. "Overall roughness" refers to a scheme with roughening at the bottom and side slope all. "-I, -II and -III" represent different scenarios under diverse flow rates.

\begin{tabular}{cccccc}
\hline \multirow{2}{*}{ Scheme } & Scenario & $\begin{array}{c}\text { Flow Rate } \\
\boldsymbol{Q}\left(\mathbf{m}^{\mathbf{3}} \mathbf{s}\right)\end{array}$ & $\begin{array}{c}\text { Depth of Water } \\
\boldsymbol{h}(\mathbf{m})\end{array}$ & $\begin{array}{c}\text { Roughness } \\
n\end{array}$ & $\begin{array}{c}\text { Average Roughness } \\
n\end{array}$ \\
\hline \multirow{3}{*}{ Original roughness } & I-1 & 0.057 & 0.055 & 0.0111 \\
\cline { 2 - 5 } & I-II & 0.045 & 0.049 & 0.0115 \\
\cline { 2 - 5 } & I-III & 0.024 & 0.035 & 0.0121 \\
\hline \multirow{3}{*}{ Bottom roughness } & II-I & 0.057 & 0.081 & 0.0219 \\
\cline { 2 - 5 } & II-II & 0.045 & 0.073 & 0.0231 \\
\hline \multirow{3}{*}{ Overall roughness } & II-III & 0.027 & 0.054 & 0.0227 \\
\cline { 2 - 5 } & III-I & 0.057 & 0.098 & 0.0308 \\
\hline
\end{tabular}

Scenario II represented the scheme with bottom roughening. During the test, concrete blocks with an equivalent particle size of $2.0 \mathrm{~cm}$ were used to simulate sand gravel, and the spacing between concrete blocks at the bottom of the channel was about $1 \mathrm{~cm}$, as shown in Figure 3. After the concrete blocks were laid at the bottom of the channel, the average value of roughness was increased to 0.023 . 
In addition, according to the research results published by Hou et al. [31], the slope could be further roughened by the quincunx roughening method. The equivalent particle size of the roughened material was $2.0 \mathrm{~cm}$, and the spacing between the particles was $12 \mathrm{~cm}$. Therefore, an overall roughness test of the channel was carried out (scenario III), and the concrete arrangement is shown in Figure 4. The overall roughness of the channel reached 0.034 .

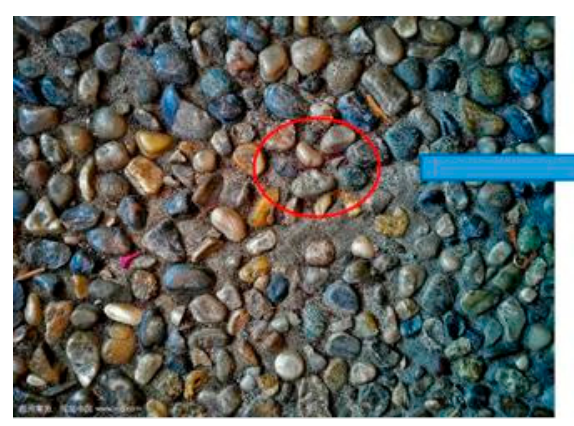

(a)

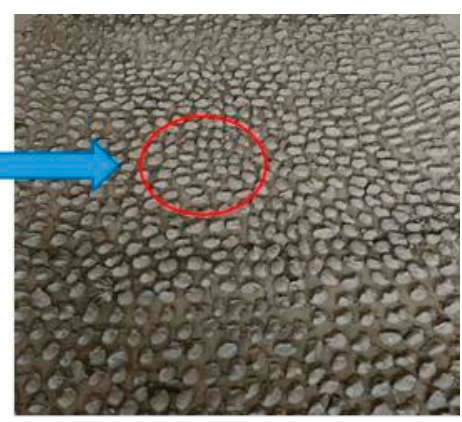

(b)

Figure 3. Simulation of sand pebbles at the bottom of the fishway: (a) Sand pebbles in prototype; (b) Simulated sand pebbles in the test. The red circle means a local region in experimental flume.

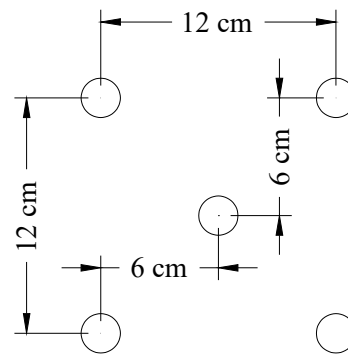

(a)

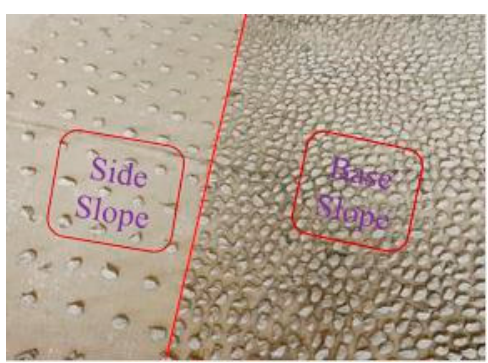

(b)

Figure 4. Roughening scheme of the side slope: (a) the schematic diagram; (b) simulated result in the test.

\subsection{Structural Design of the Pool in the Fishway}

One of the main features of the nature-like fishway is the use of natural stones to construct the inner partition wall of the fishway. The wall can be constructed to be either permeable or impermeable. In this regard, rounded cobbles were used to simulate the permeable rubble wall. The diameter of the cobbles was 10-15 cm. A brick wall was used to simulate the impermeable masonry wall. The specific layout was determined by comparing the two kinds of walls and their combined types. According to the research results on the living habits of the target fish, the migration characteristics of the four major Chinese carps are different. Therefore, this study added a design scheme using multiple fish passages to complicate the flow pattern and improve the selectivity of upstream migration paths for fish. In this regard, in addition to the water permeability of the partition wall, different widths of the fish channel and different numbers of fish passages were comparatively studied through experimental investigation. The comparison schemes are shown in Table 2. Among them, case I was the arrangement of the water-impermeable partition wall, case II was the arrangement of the permeable partition wall, and case III and case IV were the arrangements of the semi-permeable partition wall. The water permeability of the fully water-permeable partition wall was $12 \%$. The schematic diagram of the layout of each case is shown in Figure 5. From Table 2, it is seen that the thickness of the partition wall was different, but the height was the same. This is because the thickness depended on the structural stability, and the height was due to the water level. If the height was different, it would affect the discharge and flow velocity. However, the influence of the thickness could be ignored because the key 
factor of the effect on hydraulics in the pool was the uniformity of the pool length, which had a value of $1 \mathrm{~m}$ in the present study.

(1) Case I: The partition wall was constructed by impermeable brick. The layout of the wall was referenced to the layout of the vertical slot fishway. The fish passage was located on the left side of the river channel. The direction of the fish passage was $45^{\circ}$ with the main channel, and the opening width was $b=0.20 \mathrm{~m}$. The spacing of the brick walls at each level was $\mathrm{s}=1.0 \mathrm{~m}$, the height was $h=0.30 \mathrm{~m}$ and the thickness was $\mathrm{d}=0.24 \mathrm{~m}$.

(2) Case II: The partition wall was fully permeable and piled by cobbles, and the fish passage was located on the left side of the river channel. The direction was $45^{\circ}$ with the main channel, and the width was $b=0.20 \mathrm{~m}$, the spacing of the cobble walls at each level was $\mathrm{s}=1.00 \mathrm{~m}$, the height was $\mathrm{h}=0.30 \mathrm{~m}$ and the thickness was $\mathrm{d}=0.30 \mathrm{~m}$.

(3) Case III: The partition wall was semi-permeable. The height of the bottom impermeable layer was $h_{1}=0.15 \mathrm{~m}$, the height of the upper permeable layer was $\mathrm{h}_{2}=0.15 \mathrm{~m}$, the fish passage was located on one side of the bottom and the width of the fish passage was $b=0.20 \mathrm{~m}$. The spacing of the rubble walls at each level was $\mathrm{s}=1.0 \mathrm{~m}$, and the thickness was $\mathrm{d}=0.12 \mathrm{~m}$.

(4) Case IV: the height and width of the piled wall were the same as those in case III. However, the number of fish passages was increased to two, with a new fish passage arranged beside the original one. Even so, the total cross-sectional area of the fish passages remained the same. The width of the middle fish passage was $b_{1}=0.10 \mathrm{~m}$, and the side fish passage width $b_{2}$ was about $0.20 \mathrm{~m}$. In order to reduce the discharge for the fishway, the fish passages adopted an upstream and downstream staggered arrangement.

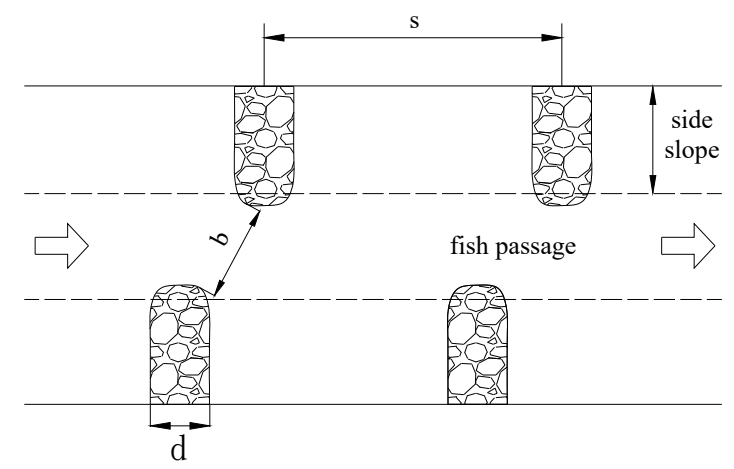

(a) Cases I-III

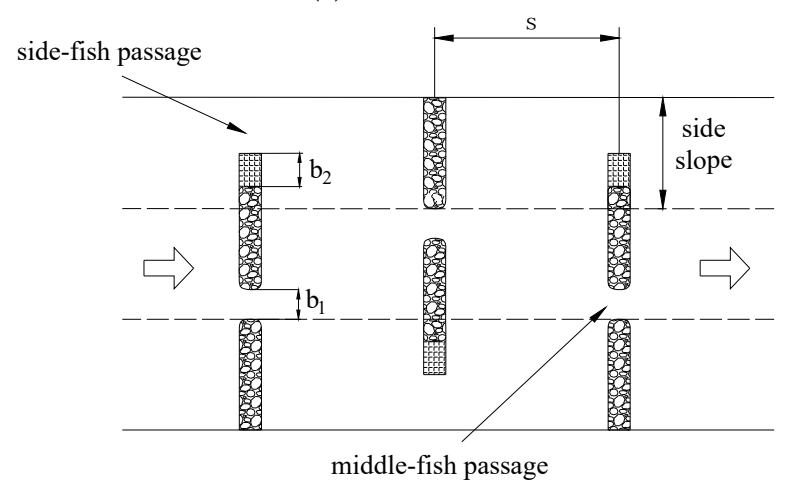

(b) Case IV

Figure 5. Schematic diagram of the layout of every scheme from a top view. (a) Nature-like fishway with one fish passage; $(\mathbf{b})$ nature-like fishway with two fish passages. $b=$ width of fish passage for case I-III; $b_{1}=$ width of middle-fish passage for case IV; $b_{2}=$ width of side-fish passage for case IV; $\mathrm{s}=$ length of a pool; $\mathrm{d}=$ thickness of the partition wall. 
Table 2. Layout parameters of every comparison scheme. "Impermeable" water permeability means the partition walls are constructed by brick only. "Fully permeable" means the partition walls are constructed by cobbles only. "Semi-permeable" means the partition walls are constructed by brick and cobbles. Substrates dimensions: brick $=24 \mathrm{~cm}$ long $\times 11.5 \mathrm{~cm}$ wide $\times 53 \mathrm{~cm}$ high; cobbles $=10$ to $15 \mathrm{~cm}$.

\begin{tabular}{|c|c|c|c|c|c|c|c|}
\hline \multirow{2}{*}{$\begin{array}{l}\text { Layout } \\
\text { Scheme }\end{array}$} & \multicolumn{3}{|c|}{ Partition Wall } & \multirow{2}{*}{$\begin{array}{l}\text { Length of Pool } \\
\text { (m) }\end{array}$} & \multicolumn{3}{|c|}{ Fish Passage } \\
\hline & Water Permeability & Thickness (m) & Height (m) & & Quantity & Width (m) & Location \\
\hline Case I & Impermeable & 0.24 & 0.30 & 1.00 & 1 & 0.20 & Stand by the main channel \\
\hline Case III & Semi-permeable & 0.12 & $0.15+0.15$ & 1.00 & 1 & 0.20 & Stand by the main channel \\
\hline Case IV & Semi-permeable & 0.12 & $0.15+0.15$ & 1.00 & 2 & $0.10-0.20$ & Staggered arrangement \\
\hline
\end{tabular}

The schematic diagram of the layout of the rubble walls of each scheme is shown in Figure 6.

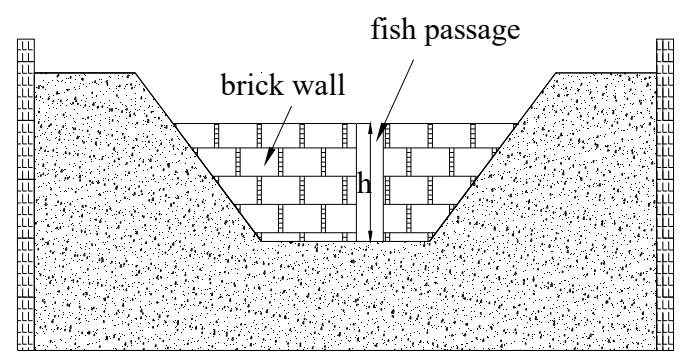

Case I

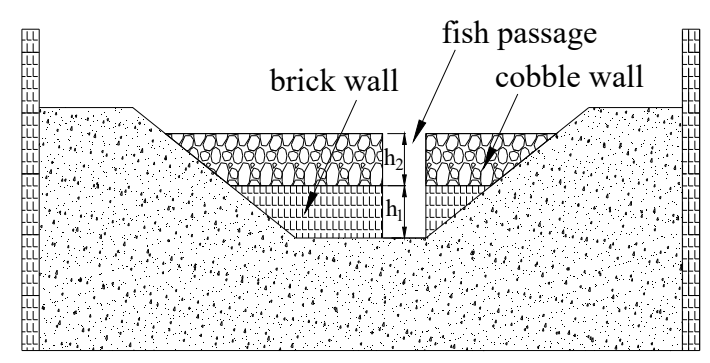

Case III

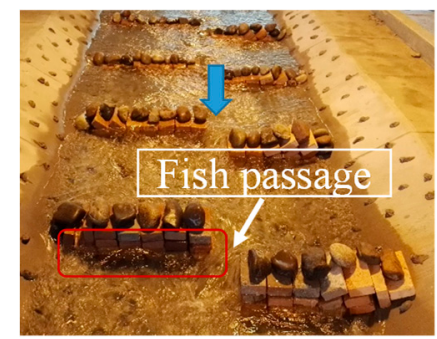

Impermeable fishway

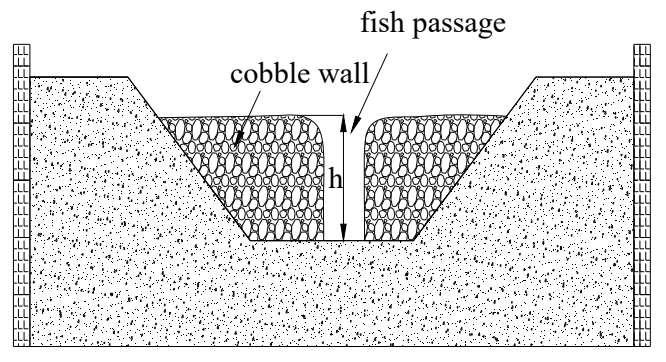

Case II

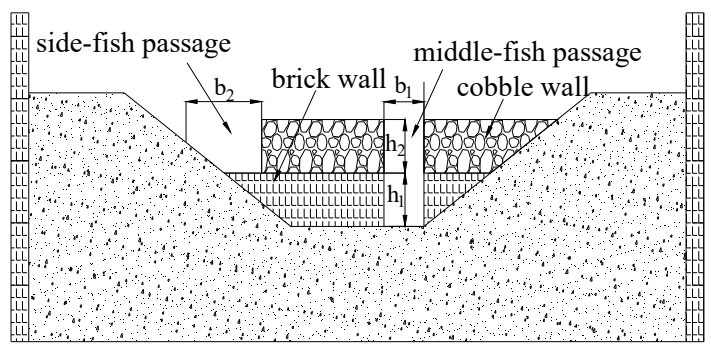

Case IV

(a)

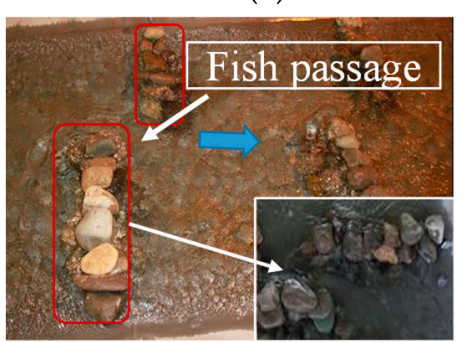

Fully permeable fishway

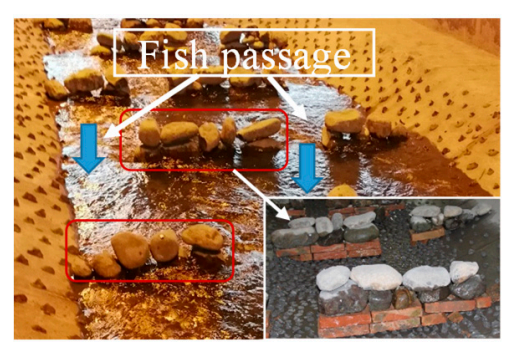

Semi-permeable fishway

(b)

Figure 6. Layout plan of rubble wall with different materials: (a) schematic diagram; (b) layout pictures in the model test. $\mathrm{h}=$ height of the partition wall for case I and case II. $\mathrm{h}_{1}=$ height of the bottom impermeable layer for case III and case IV; $h_{2}=$ height of the upper permeable layer for case III and case IV.

\subsection{Method}

During the test, the water level profile in each pool was tested with a steel ruler manufactured by Hynix. The test position was located downstream of the partition wall and contained three measuring 
points at the left, middle and right of the cross-sections. The test accuracy of the steel ruler was $0.5 \mathrm{~mm}$. The discharge of the experimental flume was recorded by an electromagnetic flow meter produced by Shanghai Guanghua Aihe Meite Instrument Co., Ltd., and its accuracy was $\pm 0.02 \%$. The velocity field in the pool was measured with a two-dimensional (2D) electric magnetic velocity meter (ACM2-RS) produced by JFE Advantech in Japan. The measurement accuracy was $\pm 2 \%$. To ensure the statistical significance of the velocity record, velocity measurements were recorded at a frequency of $60 \mathrm{~Hz}$ for a sampling period of $120 \mathrm{~s}$ for each point. Preliminary tests were conducted to define the sampling period needed for an accurate determination of the mean velocity. The tested sampling periods ranged from 20 to $180 \mathrm{~s}$. It was found that velocity became almost constant for sampling periods greater than $60 \mathrm{~s}$; therefore, a sampling time of $120 \mathrm{~s}$ was considered to be adequate for the determination of mean velocities. Flow velocities were measured at the water surface, where $\mathrm{z} / \mathrm{h}=0.17$, for a total of about 120 points located $0.10-0.20 \mathrm{~m}$ apart at the longitudinal and lateral direction separately.

\section{Results}

From a hydraulics point of view, the nature-like fishway can be regarded as a section of open channel, and its main hydraulic parameters are still water level, flow velocity and discharge [32]. Therefore, in the present study, the velocity, discharge and flow pattern were the main analysis indexes for a uniform water level $(0.30 \mathrm{~m})$ in the fishway.

\subsection{Roughness}

Channel roughness evaluation is very important in fishway hydraulics, especially for nature-like fishways [33]. Velocity and discharge relationships are influenced by channel roughness [34]. For a given slope, velocity increased as discharge increased and roughness decreased. The roughness values for the fishways of the four schemes in this paper are illustrated in Figure 7. As shown in the figure, the roughness value of case I is much larger than those of the other cases and is nearly double that of case II. This is because the partition wall for case I was constructed by brick, which is an impermeable material. When the partition wall was constructed by cobbles for case II, which is a fully permeable material, the flow resistance was be decreased and the porosity increased. For cases III and IV, the partition wall was constructed by a semi-permeable material, so the roughness was between the two extremes (increasing by about $40 \%$ compared with that of case II and decreasing $30 \%$ compared with that of case I). It should also be pointed out that the roughness values of case III and case IV were nearly the same in spite of their different numbers of fish passages. This is because the porosity of the partition walls was the same for the two cases, and the flow areas were also uniform.

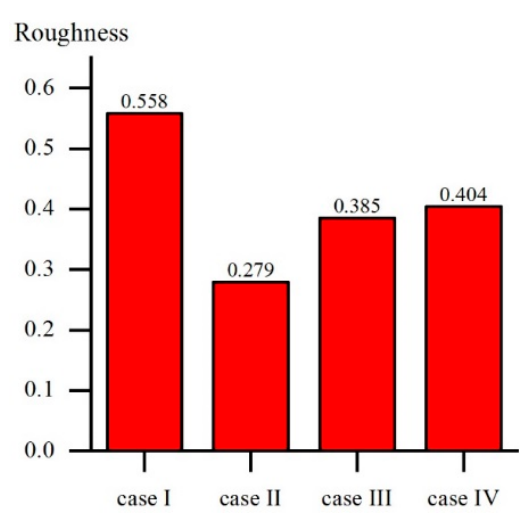

Figure 7. Comparison of the roughness for each configuration tested, calculating by discharge $\left(0.027 \mathrm{~m}^{3} / \mathrm{s}^{-1}, 0.053 \mathrm{~m}^{3} / \mathrm{s}^{-1}, 0.039 \mathrm{~m}^{3} / \mathrm{s}^{-1}\right.$ and $0.037 \mathrm{~m}^{3} / \mathrm{s}^{-1}$ for cases I-IV, respectively), water depth $(0.3 \mathrm{~m})$ and longitudinal slope $(1 \%)$. 


\subsection{Discharge}

Discharge is one of the important indicators that need to be considered when a fishway project is selected and implemented [35]. A larger discharge means that more abandoned water will be generated from the gated dam, which will affect the operational benefits of the project. Figure 8 compares the results of the discharge under different fishway schemes. The results show that the discharge of the fishway of each case was quite different. The discharge of the fishway constructed by the impermeable partition wall was only $0.027 \mathrm{~m}^{3} / \mathrm{s}$ (case I). The discharge of the fishway constructed by a permeable partition wall was $0.053 \mathrm{~m}^{3} / \mathrm{s}$ (case II), which is twice the discharge of case I. When the rubble wall was made of a combination of permeable cobbles and impermeable material (case III), the wetted cross-sectional area of the fishway channel was increased compared with that of the case I and was reduced compared with that of case II, so the discharge of the fishway for case III was $0.039 \mathrm{~m}^{3} / \mathrm{s}$. Compared with case III, the number of fishway channels was double in case IV, but the total cross-sectional area of the fishway channels was unchanged. Under this condition, the discharge of the fishway was reduced to $0.037 \mathrm{~m}^{3} / \mathrm{s}$.

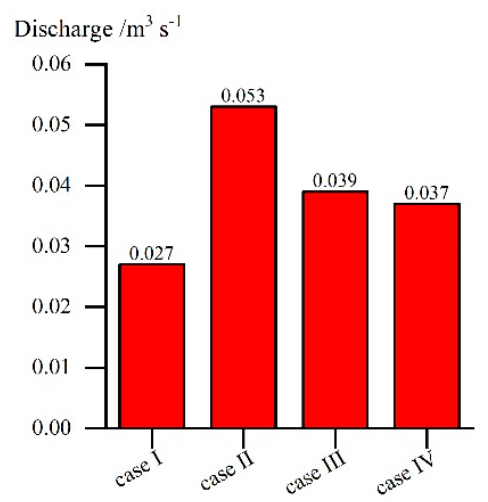

Figure 8. Comparison of the discharge magnitude $\left(\mathrm{m}^{3} \mathrm{~s}^{-1}\right)$ for each configuration tested, using an electromagnetic flowmeter.

\subsection{Flow Velocity}

According to the basic principles for fishway design, the maximum flow velocity in the fishway pond generally appears near the inlet of the fishway. Its size determines whether the fish can successfully pass through the pool. The flow velocity in the fish passage is the main fishway design indicator, the value of which should not exceed the burst swimming speeds of the fish [36]. Figure 9 shows the comparison of the average flow velocity at the cross-section of the fish passage. In the figure, the velocities of flows M-F and S-F in case IV represent the average of the cross-sectional flow velocity in the middle fish passage and side fish passage (as shown in Figure 6), respectively. It can be seen from the figure that the maximum flow velocity of the fishway occurred in case II, in which the flow velocity reached $0.69 \mathrm{~m} / \mathrm{s}$. Under the other three schemes, the average flow velocity in the fish passage was only $0.45-0.55 \mathrm{~m} / \mathrm{s}$.

\subsection{Flow Pattern}

The flow pattern in a fishway is one of the key indicators affecting the migration rate [35-37]. The distribution of the mainstream area in the pool should not be too concentrated, and it is not appropriate to form a wide range of recirculation areas on both sides of the mainstream, so the fish in the rest area can quickly find the mainstream and continue on their way. There should be more diverse flow conditions in the rest area of a pool in order to mimic the natural environment, and it can provide a place for fish to rest, forage and migrate. Figure 10 is the measured velocity vectors in the central pool at the surface for the different cases. The magnitude and direction of the flow velocity in the pool were measured at $2 \mathrm{~cm}$ below the water surface with a velocity meter (ACM2-RS). The magnitude of the flow 
velocity, $U$, was calculated by $U=\sqrt{u^{2}+v^{2}}$ at all measurement points in the detailed measurement area. Herein, $\mathrm{u}$ and $\mathrm{v}$ are the time-averaged streamwise and lateral velocities, respectively.

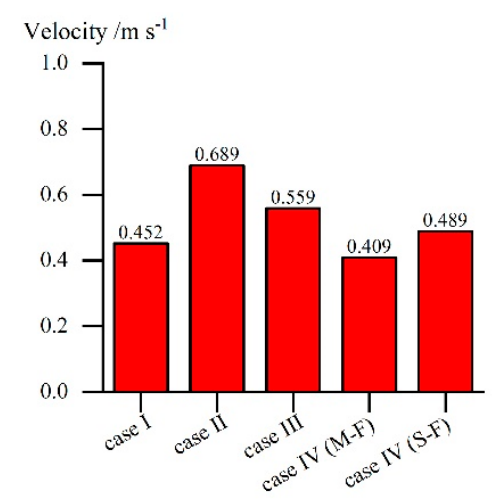

Figure 9. Comparison of the mean water velocity magnitude $\left.\left(U=\sqrt{\mathrm{u}^{2}+\mathrm{v}^{2}}\right), \mathrm{m} \mathrm{s}^{-1}\right)$ for each configuration tested at the cross-section of the fish passage, using a two-dimensional (2D) electric magnetic velocity meter. $\mathrm{U}=$ mean water velocity magnitude; $\mathrm{u}=$ time-averaged streamwise velocity; $\mathrm{v}=$ time-averaged lateral velocity.
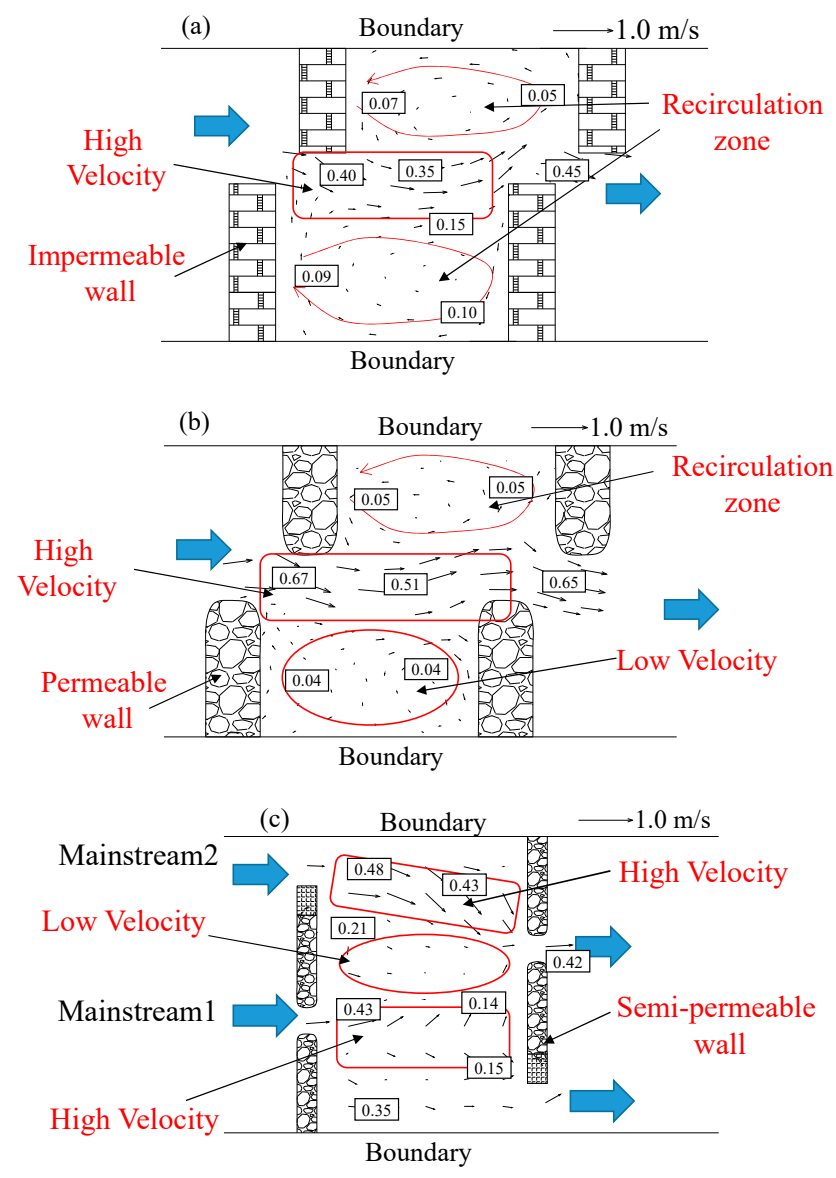

Figure 10. Measured velocity vectors in the central pool at the surface for (a) case I; (b) case II/III; (c) case IV. The units of the values in small black rectangles are $\mathrm{m} / \mathrm{s}$ all.

Under the impermeable condition (case I), the flow pattern distribution was basically the same as that of the technical fishway [38]. The flow velocity distribution was relatively simple, the mainstream area was concentrated, and two recirculation zones were formed in the rest zone, as shown in Figure 10a. The flow velocity in the zone between the mainstream and backflow was close to zero. In contrast to 
the flow pattern of case I, when the partition wall was constructed by fully- or semi-water-permeable material, such as in cases II and III, more diverse flow conditions were formed at the surface of the pool. Figure $10 \mathrm{~b}$ shows that the mainstream was no longer concentrated, and the two recirculation zones on both sides of the mainstream diminished or disappeared. However, there was still a relatively high flow velocity zone at the fish passage, which would exceed the critical swimming speed of most migratory fish for a project in China. On the basis of the hydraulic theory, if the discharge is uniform, then the larger the flow area, the smaller the flow velocity. Hence, in the present study, an increase in the number of fish passages was put forward to increase the flow area. In order to control the discharge and flow velocity, two fish passages were staggered left and right, as shown in Figure 6. It was found that two mainstreams were formed in the fishway for the case with two fish passages, as shown in Figure 10c. Three flow regions were formed in the pool by the two mainstreams, with two high flow velocity regions and one low flow velocity region. The flow velocity in the low flow velocity region was about $0.02-0.30 \mathrm{~m} / \mathrm{s}$, and a weak recirculation zone was formed inside the region, which could serve as a rest zone for migratory fish. The average flow velocity in the high velocity regions was about $0.50 \mathrm{~m} / \mathrm{s}$, which meets the swimming speed of most migratory fish in China.

\section{Discussion}

Discharge, flow velocity and flow pattern are key indicators for fishway designs [39]. On the basis of physical experiments, the present paper analyzes the differences in key indicators for nature-like fishways under four kinds of partition walls with different water permeabilities. From the analysis of the discharge, although the total cross-sectional area of the fish passage was the same, it was found that the discharge of the nature-like fishway with the permeable partition wall was much larger than that of the fishway with the impermeable partition wall. This was because the gaps inside the permeable partition walls piled with cobbles increased the wetted cross-sectional area of the fishway. Under the same running water depth, nature-like fishways with a permeable wall needed to consume more water than that consumed with a watertight partition wall. In addition, the local water head loss of the permeable partition wall was reduced by more than that of the impermeable partition wall, thereby further increasing the discharge of the fishway, which in turn led to an increase in the flow velocity in the fishway as shown in Figure 10. When the water permeability was $12 \%$, calculations of the flow area of the permeable partition wall showed that the discharge was $0.053 \mathrm{~m}^{3} / \mathrm{s}$, the mean flow velocity at the fish passage was $0.689 \mathrm{~m} / \mathrm{s}$ and the mean velocity in the gaps between the cobbles was about $0.3 \mathrm{~m} / \mathrm{s}$, which is consistent with the simulation results in the literature [40]. When the partition wall was semi-permeable, the discharge of the nature-like fishways was reduced compared with that of nature-like fishways with a fully permeable partition wall, but it was larger than that of fishways with an impermeable partition wall. For the condition in which the nature-like fishway contained two fish passages arranged in an interlaced manner, the discharge did not increase much compared with the single fish passage condition, but the mainstream velocity was significantly reduced.

Discharge of the fishway affects the operational efficiency of a dam project. Moreover, the flow velocity in the fish passage will determine whether the fish can migrate back, and the flow pattern is the key factor in determining the duration of fish migration [41]. The experimental results showed that when the partition wall was impermeable, the flow pattern in the pool was single, which is similar to that of the technical fishway [39]. However, the motivation for the construction of nature-like fishways is to enrich the flow pattern in the fishway so that it mimics the flow pattern in a natural river $[13,16,37]$. In other words, nature-like fishways that use impermeable partition walls will not produce hydrodynamic and morphological properties that are similar to those of natural rivers, which are best-suited to the original purpose of fishways. From the perspective of discharge and flow velocity control, this paper proposes a new kind of fish passage arrangement with semi-permeable partition walls. The related hydraulic indicators for a fishway with a single fish passage and two fish passages were compared and analyzed. The study found that when using two fish passages, the discharge and cross-sectional flow velocity of the fishway were reduced, and two mainstreams 
were formed in the fishway pool. Some studies have found that fish generally tend to avoid flows with unpredictable high-velocity fluctuations or recirculation flow that interferes with swimming trajectories $[2,42,43]$. From the prior analyses, it was found that obvious recirculation flow was formed for the nature-like fishway of types I, II and III, which is disadvantageous for fish migration. In contrast, the two fish passages in the type IV nature-like fishway were in an interlaced arrangement, the flow information in the pool became more complex (including some small vertical eddies and back-flow swirls), and no obvious recirculation zones were formed, which is conducive to the migration of fish. Furthermore, water flows past the cobbles and velocity gradients are created, which form small vortices that interact with each other and decay over different time courses. Many studies have shown that small vortical flows provide an energy-rich environment that can be exploited to enhance swimming performance $[41,44,45]$. It could be concluded that, compared with the other three types of nature-like fishways explored in the present study, type IV is much more suitable for fish migration. In addition, the two fish passages had different bottom elevations and widths, which can provide favorable conditions for the upstream migration of fish with different sizes and body types. In the migration season, different species of fish of various sizes and habits need to run upstream in rivers. Some fish like swimming on the water surface, and some like swimming on the bottom. Because of the larger width and high bottom elevation, the side passage of type IV is advantageous for fish swimming on the water surface to successfully negotiate the fish passage, especially bigger fish. In contrast, the middle passage is only suitable for little fish because of the small width, but this applies to all fish, regardless of whether they swim on the surface or the bottom.

Under the premise that the plane dimensions and the slope of the fishway are given, the relationship among discharge, flow velocity and water depth is reflected by the roughness factor (n). If the roughness is low, the flow velocity in the fishway will be high, and the presence of large high velocity regions could make it difficult for protected fish to complete upstream migration. At the same time, if the flow velocity is higher under the same flow discharge, the water depth will be shallower, but it is necessary to keep sufficient water depth in the fishway by using a larger flow discharge. However, if the roughness is too high, the water surface elevation will be higher than that with low roughness, which may induce a lower flow velocity. In terms of the swimming habits of fish, lower velocity flow would be less attractive for migration, which will result in low efficiency of the nature-like fishway $[46,47]$. It can be seen that for nature-like fishways, the first necessity is to find an appropriate range of roughness values to form a generally uniform flow structure throughout the water depth. The calculation results of the overall roughness for the fishways of the four schemes in this paper are shown in Figure 7. Combined with the previous analysis, it is well recognized that all four flow schemes can form a suitable flow pattern in the fishway. Different roughness coefficients correspond to different discharges and flow velocities for the fishway.

\section{Conclusions}

This paper proposes four nature-like fishway types arranged with impermeable, fully permeable and semi-permeable partition walls, and it compares the hydraulic characteristics of the various fishways through physical experiments. The comparative study found that if the partition wall in the fishway is constructed by permeable materials, then more discharge will be needed, and the flow velocity in the fish passage will be larger than that of a fishway constructed by permeable materials. However, the flow pattern information is more complex, with some small vortical flows, especially for the fishway with two fish passages. In order to decrease the discharge and flow velocity, the nature-like fishway could be constructed by semi-permeable materials. The present study focused primarily on flow characteristics in a nature-like fishway, such as the roughness, flow velocity and discharge. In recent years, researchers have identified some important turbulence parameters in relation to fish passage, e.g., turbulence intensity, turbulent kinetic energy, Reynolds shear stress, vorticity and eddy sizes $[26,48]$. Therefore, the turbulence characteristics in the nature-like fishways described in the 
present paper should be studied next. In addition, experiments with specific fish to evaluate the efficiency of nature-like fishways should also be performed.

Author Contributions: T.Z. performed the laboratory work, did the analysis and prepared the manuscript; Z.N. did the analysis, contributed to manuscript preparation and English version writing; J.S. and S.S. performed the laboratory work and provided the funding; H.L. and G.L. contributed to the laboratory and the analysis work. All authors have read and approved the final manuscript.

Funding: The research in this paper is funded by the National Key Research and Development Program of China (no. 2016YFC0401708 and 2018YFC1505004), the National Key Laboratory Team Key Project of China (no. SKL2018ZY08), the Fundamental Research Funds for IWHR (no. HY0145B162019), the Fundamental Research Funds for the Central Universities (no. YJ201832), the National Natural Science Foundation of China (no. 51679261, 51709278), and the Sichuan application basic research project (no. 20YYJC4057).

Conflicts of Interest: The authors declare no conflict of interest.

\section{References}

1. Clay, C.H. Design of Fishways and Other Fish Facilities, 2nd ed.; CRC Press: Boca Raton, FL, USA, 1994.

2. FAO; DVWK. Fish Passes-Design, Dimensions and Monitoring (English version of DVWK); FAO: Roma, Italy, 2002.

3. Chen, K.Q.; Chang, Z.N.; Cao, X.H.; Ge, H.F. Status and prospection of fish pass construction in China. J. Hydraul. Eng. 2012, 43, 182-188.

4. Zheng, T.G.; Sun, S.K.; Liu, H.T.; Jiang, H.; Li, G.N. Location choice of fishway entrance in hydropower project based on fish behavioristics and hydraulics. Trans. Chin. Soc. Agric. Eng. (Trans. CSAE) 2016, 32, 164-170.

5. Katopodis, C.; Williams, J.G. The development of fish passage research in a historical context. Ecol. Eng. 2011, 48, 8-18. [CrossRef]

6. Sun, S.K.; Zhang, G.Q. Environment-friendly fishway in close-to-nature types. J. China Inst. Water Resour. Hydropower Res. 2012, 10, 41-47.

7. Bunt, C.M.; Castro-Santos, T.; Haro, A. Performance of fish passage structures at upstream barriers to migration. River Res. Appl. 2012, 28, 457-478. [CrossRef]

8. Katopodis, C.; Kells, J.A.; Acharya, M. Nature like and conventional fishways: Alternative concepts? Can. Water Resour. J. 2001, 26, 211-232. [CrossRef]

9. Stephan, U.; Schotzko, N.; Haunschmid, N.; Petz-Glechner, R.; Ullmann, M. Development of a fish migration ramp-Field and laboratory experiments. In Proceedings of the 6th International Symposium on Ecohydraulics, Christchurch, New Zealand, 19-23 February 2007.

10. Link, O.; Sanhueza, C.; Arriagada, P.; Brevis, W.; Laborde, A.; González, A.; Wilkes, M.; Habit, E. The fish Strouhal number as a criterion for hydraulic fishway design. Ecol. Eng. 2017, 103, 118-126. [CrossRef]

11. Baek, K.O.; Ku, Y.H.; Kim, Y.D. Attraction efficiency in natural-like fishways according to weir operation and bed change in Nakdong River, Korea. Ecol. Eng. 2015, 84, 569-578. [CrossRef]

12. Jungwirth, M. Bypass channels at weirs as appropriate aids for fish migration in rhithral rivers. Regul. Rivers Res. Manag. 1996, 12, 483-492. [CrossRef]

13. Bretón, F.; Baki, A.B.M.; Link, O.; Zhu, D.Z.; Rajaratnam, N. Flow in nature-like fishway and its relation to fish behaviour. Can. J. Civ. Eng. 2013, 40, 567-573. [CrossRef]

14. Aarestrup, K.; Lucas, M.C.; Hansen, J.A. Efficiency of a nature-like bypass channel for sea trout (Salmo trutta) ascending a small Danish stream studied by PIT telemetry. Ecol. Freshw. Fish 2010, 12, 160-168. [CrossRef]

15. Kim, J.H.; Yoon, J.D.; Baek, S.H.; Park, S.H.; Lee, J.W.; Lee, J.A.; Jang, M.H. An efficiency analysis of a nature-like fishway for freshwater fish ascending a large Korean river. Water 2016, 8, 3. [CrossRef]

16. Wang, R.W.; Hartlieb, A. Experimental and field approach to the hydraulics of nature-like pool-type fish migration facilities. Knowl. Manag. Aquat. Ecosyst. 2011, 400, 5. [CrossRef]

17. Larinier, M.; Travade, F.; Porcher, J.P. Fishways: Biological basis, design criteria, and monitoring. Bulletin Français de la Pêche et de la Pisciculture 2002, 364, 1-208.

18. Haro, A.; Franklin, A.; Castro-santos, T.; Noreika, J. Design and Evaluation of Nature-Like Fishways for Passage of Northeastern Diadromous Fishes. S. O. Conte Anadromous Fish Research laboratory (CAFRL), U.S. Geological Survey, Biological Resource Division. NOAA Final Report; 2008; pp. 1-35. Available online: https://repository.library.noaa.gov/view/noaa/4015/noaa_4015_DS1.pdf (accessed on 27 March 2020). 
19. Muraoka, K.; Nakanishi, S.; Kayaba, Y. Boulder arrangement on a rocky ramp fishway based on the swimming behavior of fish. Limnologica 2017, 62, 188-193. [CrossRef]

20. Tran, T.D.; Chorda, J.; Laurens, P.; Cassan, L. Modelling nature-like fishway flow around unsubmerged obstacles using a 2D shallow water model. Environ. Fluid Mech. 2016, 16, 413-428. [CrossRef]

21. Larinier, M.; Courret, D.; Gomes, P. Technical Guide to the Concept on nature-like Fishways. Rapp. GHAAPPE $R A$ 2006, 06.05-V1, 5.

22. Wildman, L.; Parasiewicz, P.I.O.T.R.; Katopodis, C.H.R.I.S.T.O.S.; Dumont, U.L.R.I.C.H. An Illustrative Handbook on Nature-like Fishways: Summarized Version; American Rivers: Washington, DC, USA, 2000.

23. Lacey, R.W.J.; Rennie, C.D. Laboratory investigation of turbulence flow structure around a bed mounted cube at multiple flowstages. J. Hydraul. Eng. ASCE 2012, 138, 71-84. [CrossRef]

24. Acharya, M.; Kells, J.A.; Katopodis, C. Some Hydraulic Design Aspects of Nature-Like Fishways. In Proceedings of the Joint Conference on Water Resource Engineering and Water Resources Planning and Management, Minneapolis, MN, USA, 30 July-2 August 2000.

25. Baki, A.B.M.; Zhu, D.Z.; Rajaratnam, N. Mean flow characteristics in a rock-ramp-type fishpass. J. Hydraul. Eng. ASCE 2014, 140, 156-168. [CrossRef]

26. Baki, A.B.M.; Zhu, D.Z.; Rajaratnam, N. Turbulence characteristics in a rock-ramp type fishpass. J. Hydraul. Eng. ASCE 2015, 141, 156-168. [CrossRef]

27. He, Y.M.; An, R.D.; Li, J.; Yi, W.M.; Zeng, Z. Hydraulic characteristics of nature-like fishways of rock-ramp type. J. Hydroelectr. Eng. 2016, 35, 40-47.

28. Xu, J.C.; Wang, X.G.; Xuan, G.X.; Zheng, F.D.; Huang, Y. Physical model test study on nature-like fishways. Adv. Water Sci. 2017, 28, 879-887.

29. Lin, N.Y.; An, R.D.; Li, J.; Yi, W.M.; Xie, C.H.; Xu, Y.Y. Study on Hydraulic Characteristics of Nature-like Fishway of Interlaced Stonewall shape. Water Resour. Power 2017, 35, 82-85.

30. Dodd, J.R.; Cowx, I.G.; Bolland, J.D. Efficiency of a nature-like bypass channel for restoring longitudinal connectivity for a river-resident population of brown trout. J. Environ. Manag. 2017, 204, 318-326. [CrossRef]

31. Hou, Z.J.; Hou, J.J.; Sun, Y. Roughness simulated method for fixed-bed model trial test. Yellow River 2014, 36, 13-15.

32. Franklin, A.E.; Haro, A.; Castro-Santos, T.; Noreika, J. Evaluation of nature-like and technical fishways for the passage of alewives at two coastal streams in New England. Trans. Am. Fish. Soc. 2012, 141, 624-637. [CrossRef]

33. Plesiński, K.; Bylak, A.; Radecki-Pawlik, A.; Mikołajczyk, T.; Kukuła, K. Possibilities of fish passage through the block ramp: Model-based estimation of permeability. Sci. Total Environ. 2018, 631-632, 1201-1211. [CrossRef]

34. Wohl, E.E.; Ikeda, H. The effect of roughness configuration on velocity profiles in an artificial channel. Earth Surf. Process. Landf. 1998, 23, 159-169. [CrossRef]

35. Wu, S.; Rajaratnam, N.; Katopodis, C. Structure of Flow in Vertical Slot Fishway. J. Hydraul. Eng. ASCE 1999, 125, 351-360. [CrossRef]

36. Rajaratnam, N.; Katopodis, C.; Solanki, S. New design for vertical slot fishways. Can. J. Civ. Eng. 2011, 19, 402-414. [CrossRef]

37. Amaral, S.D.; Quaresma, A.L.; Branco, P.; Romão, F.; Katopodis, C.; Ferreira, M.T.; Pinheiro, A.N.; Santos, J.M. Assessment of retrofitted ramped weirs to improve passage of potamodromous fish. Water 2019, 11, 2441. [CrossRef]

38. Marriner, B.A.; Baki, A.B.M.; Zhu, D.Z.; Cooke, S.J.; Katopodis, C. The hydraulics of a vertical slot fishway: A case study on the multi-species Vianney-Legendre fishway in Quebec, Canada. Ecol. Eng. 2016, 90, 190-202. [CrossRef]

39. Wang, R.W.; Davi, L.; Larinier, M. Contribution of experimental fluid mechanics to the design of vertical slot fish passes. Knowl. Manag. Aquat. Ecosyst. 2010, 396, 2. [CrossRef]

40. Li, G.N.; Sun, S.K.; Liu, H.T.; Zhang, C.; Zhao, G.X.; Zheng, T.G. Improving effect of hydraulic characteristics of nature-like fishway with pools and cobblestone weirs. Trans. Chin. Soc. Agric. Eng. (Trans. CSAE) 2017, 33, 184-189.

41. Liao, J.C. A review of fish swimming mechanics and behavior in altered flows. Philos. Trans. R. Soc. B 2007, 362, 1973-1993. [CrossRef] 
42. Videler, J.J.; Wardle, C.S. Fish swimming stride by stride: Speed limits and endurance. Rev. Fish Biol. Fish. 1991, 1, 23-40. [CrossRef]

43. Enders, E.C.; Boisclair, D.; Roy, A.G. The effect of turbulence on the cost of swimming for juvenile Atlantic salmon (Salmo salar). Can. J. Fish. Aquat. Sci. 2003, 60, 1149-1160. [CrossRef]

44. Weihs, D. Hydromechanics of fish schooling. Nature 1973, 241, 290-291. [CrossRef]

45. Liao, J.C.; Beal, D.N.; Lauder, G.V.; Triantafyllou, M.S. Fish exploiting vortices decrease muscle activity. Science 2003, 302, 1566-1569. [CrossRef]

46. Pavlov, D.S.; Lupandin, A.I.; Skorobogatov, M.A. The effects of flow turbulence on the behavior and distribution of fish. J. Ichthyol. 2000, 40, 232-261.

47. Lupandin, A.I. Effect of Flow Turbulence on Swimming Speed of Fish. Biol. Bull. 2005, 32, 461-466. [CrossRef]

48. Tan, J.; Gao, Z.; Dai, H.; Yang, Z.; Shi, X. Effects of turbulence and velocity on the movement behaviour of bighead carp (Hypophthalmichthys nobilis) in an experimental vertical slot fishway. Ecol. Eng. 2019, 127, 363-374. [CrossRef]

(C) 2020 by the authors. Licensee MDPI, Basel, Switzerland. This article is an open access article distributed under the terms and conditions of the Creative Commons Attribution (CC BY) license (http://creativecommons.org/licenses/by/4.0/). 